\author{
측두골을 침범한 다발성 골수종 1 예 \\ 전북대학교 의과대학 이비인후-두경부외과학교실 \\ 최승철 · 이재근 · 윤용주
}

\title{
A Case of Multiple Myeloma Involving Temporal Bone
}

\author{
Seung Choul Choi, MD, Jae Keun Lee, MD and Yong Joo Yoon, MD \\ Department of Otolaryngology-Head and Neck Surgery, School of Medicine, \\ Chunbuk National University, Jeonju, Korea
}

\begin{abstract}
-ABSTRACT -
Multiple myeloma (MM) is a systemic manifestation of plasma cell tumor. MM is a relatively well known disease, but the involvement of temporal bone is very rare. In 1979, Lavin first reported the involvement of temporal bone in MM. Symptoms of MM with involvement of temporal bone include hearing loss, tinnitus, dizziness, facial paralysis, and otalgia. The diagnosis of MM may be considered in the presence of a temporal bone mass. Recently, we experienced a case with tinnitus, hearing impairment, and temporal bone mass. The case was later confirmed to be a MM after a pathologic review and a systemic evaluation. We report this rare case with literature reviews. (J Clinical Otolaryngol 2004;15:299-302)
\end{abstract}

KEY WORDS : Multiple myeloma - Temporal bone $\cdot$ Tinnitus.

\section{서 론}

형질세포종양은 1846년 Darly mpic과 Bence- Jone' $\mathrm{s}^{1)}$ 에 의해서 처음 보고된 이후, Willis ${ }^{2}$ 가 임상 및 병리학 적 양상에 따라서 다발성 골수종, 고립성 골형질세포종 및 골수외 형질세포종으로 분류하였다. 이들 중, 전신적 이환 형태인 다발성 골수종이 대부분을 차지하며, 국소 적 형태는 전체 형질세포종양의 $10 \%$ 이하로 드물게 발견 된다. 측두골에 이환된 다발성 골수종인 경우, 1979년 처

논문접수일 : 2004년 9월 23일

심사완료일 : 2004년 11월 23일

교신저자 : 최승철, 561- 712 전북 전주시 덕진구 금암동

634- 18 전북대학교 의과대학 이비인후- 두경부외과학교실

전화 : (063) 250- 1980. 전송 : (063) 250- 1986

E- mail : iceboy44@freechal.com
음 Lavine 등헤 에 의해 보고된 이후 드물게 보고되고 있다. 최근 저자들은 청력감소와 이명, 그리고 측두골 부위의 종물을 주소로 내원한 환자에 대해, 수술 후 조직병리학 적 소견과 전신적인 평가를 통해 다발성 골수종으로 진 단 받은 증례를 경험하였기에 문헌 고찰과 함께 보고하 는 바이다.

\section{증 례}

54세 여자 환자로 1년 전부터 시작된 좌측의 난청과 이명, 그리고 측두부에 발생한 종물을 주소로 내원하였 다. 과거력상 특이 소견은 없었다. 이학적 검사상 좌측 외 이도의 연골 부분이 부드러운 표면을 가진 종괴에 의해 거의 폐쇄되어 고막을 관찰할 수 없었다. 순음청력검사 상 좌측 기도청력과 골도청력이 각각 평균 $70 \mathrm{~dB}, 15 \mathrm{~dB}$ 인 전음성 난청 소견을 보였다. 내원 후 실시한 측두골 전 


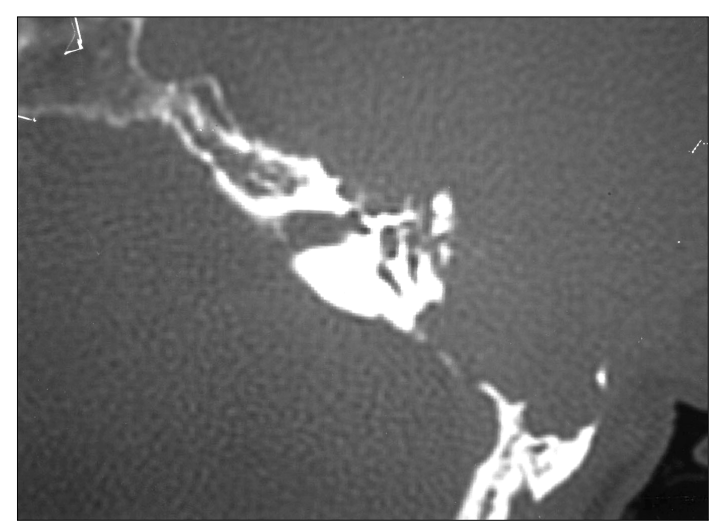

Fig. 1. The axial CT scan of temporal bone. CT scan shows a huge soft tissue density in the mastoid cavity and bony destructive lesion of mastoid.

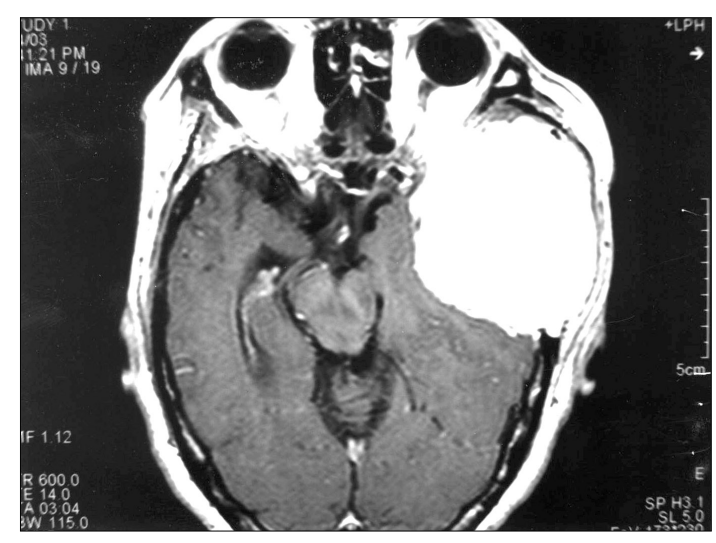

Fig. 2. The contrast-enhanced T1-weighted MRI. The T1weighted MRI image with gadolinium-DPTA shows homogeneously enhanced mass on temporal area.

산화단층촬영 상 좌측 측두골과 외이도의 골 파괴를 일 으킨, 경계가 잘 지워지는 연조직 종괴가 보였다 Fig. 1). 뇌자기공명영상 T1 강조영상에서 고신호강도를 보이고 (Fig. 2), T 2 강조영상에서 뇌조직과 비슷한 신호강도를 보이는 종물이 보였다.

임상소견과 방사선학적 검사상 뇌수막종이 의심되어 신 경외과에서 전신 마취하에 수술하였다. 수술 소견상 연 노란색의 연부조직의 종괴가 주위와 유착없이 경계가 잘 지워져 있었으며, 측두골의 광범위한 골파괴가 관찰되었 다. 동결절편에 대한 조직 병리학적 소견상 형질세포 종 양임을 확인하였다. 수술은 종괴만 떼어내고 일차 봉합을 하였다. 수술 후 청력은 변화 없었으며, 안면 신경 마비

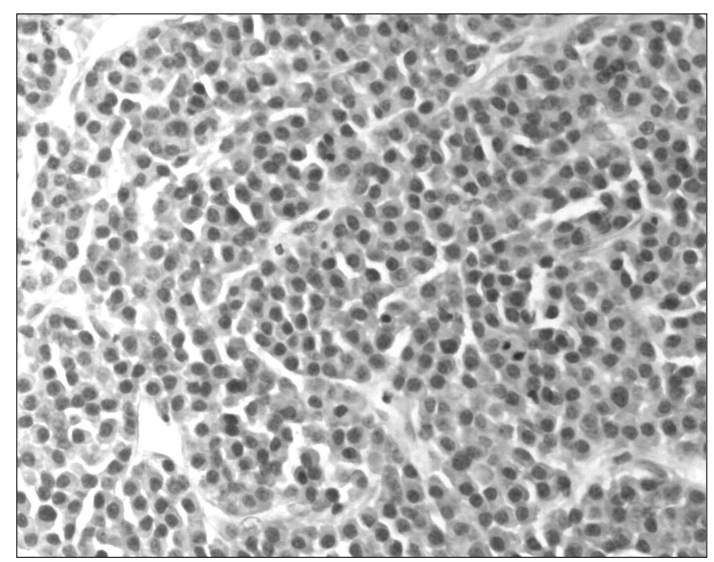

Fig. 3. The lesion is composed of a dense cellular infiltrate, mainly atypical plasma cells ( $H \& E, \times 400)$.

\section{등의 합병증은 없었다.}

수술 후 환자는 형질세포 종양에 대한 전신적인 검사를 실시하였다. 말초혈액 도말검사상 백혈구 $6,400 / \mathrm{mm}^{3}$, 혈 소판 $145,000 / \mathrm{mm}^{3}$ 로 정상 소견 보였고 혈색소는 9.3 $\mathrm{g} / \mathrm{dl}$ 로 감소된 소견을 보였다. 생화학 검사상 $\beta_{2}$ 마이크 로 글로불린 $4.6 \mathrm{mg} /$, 혈청 총단백 $10.1 \mathrm{~g} / \mathrm{dL}$, 알부민 과 글로불린이 각각 4.4 와 $5.7 \mathrm{~g} / \mathrm{dL}$ 로 알부민/글로불린 비율이 0.8로 나타났다. 혈청 IgG가 $2170 \mathrm{mg} / \mathrm{dL}$ 로 증 가된 반면, 혈청 $\operatorname{lgA}, \operatorname{lgM}$ 등은 감소되었다. 혈청 단백 전기영동 검사상 $\mathrm{M}$ - 첨형 단백이 감마영역에서 관찰되었 고, 소변 면역전기영동에서는 Bence- Jones 단백이 음 성 소견을 보였다. 장골에서 시행한 골수 생검상 비정형 형질세포의 비율이 $90 \%$ 를 보이는 과세포성 골수의 소 견을 보이고 있었다. 조직 검사 소견상 육안적으로 연황 색을 띠며 비교적 단단한 고형성 종괴이었다. 현미경 소 견상 비정형 형질세포들이 관찰되었으며 면역 조직화학 염색상 IgG와 K 쇄 양성이었다(Fig. 3).

이상의 소견으로 본 형질세포 종양은 다발성 골수종으 로 확진되었고 Vincristin(0.4 mg)과 adriamy $\operatorname{cin}(13$ $\mathrm{mg}$ ) 을 4일간, dex amethasone( $28 \mathrm{mg}$ ) 을 5일간 투여 하는 화학요법을 6주 간격으로 두차례 시행하였다. 수 술 후에 이명은 호전되었으나 청력은 변화를 보이지 않 았다. 향후 1 차례 화학요법 후 자가골수이식을 계획하 고 있다. 


\section{고 찰}

형질세포종은 다발성 골수종, 고립성 골형질세포종, 골 수외 형질세포종의 3 가지군으로 분류되고 있다. 다발성 골수종의 평균 발병 나이는 52세이고, 40 대 이전에는 드 문 것으로 알려져 있으며, 남성이 조금 많은 편이다. ${ }^{4}$ 6) 미국과 유럽의 발생률은 10 만명 중 3 명 정도로 추정되 며, 국내보고에 의하면 발생률은 인구 10 만명당 0.2 명으 로 추정된다. ${ }^{5}$

다발성 골수종의 진단은 미국의 Southwest Oncology Group(SWOG) 이 제시한 기준이 보편적으로 사용되고 있다. 진단기준으로는 골수에서 비정상적인 형질세포가 $10 \%$ 이상이거나 또는 조직학적으로 진단된 형질세포종, 소변이나 혈청에서의 $\mathrm{M}$ 단백의 검출, 그리고 용해성 골 병변이나 병적골절 등이 있다. 위 3 가지 항목을 충족할 때 다발성 골수종으로 진단을 내릴 수 있지만, 점진적인 $\mathrm{M}$ 단백의 증가와 연관된 골수의 비정상적인 형질세포 증 가의 경우나, 골수외 형질세포종의 경우는 용해성 골병 변이 없어도 진단을 내릴 수 있다.

측두골에 이환된 다발성 골수종은 1979년 처음 Lavine 등에 의해 보고된 이훌) 드물게 보고되고 있고, 국 내에서는 2002년 Kim 등ㄱㅇㅔ 의해 처음 보고 된 이후 보고된 증례가 없다.

다발성 골수종의 치료는 alky lating제제 등의 항암치료 에 의해 평균 생존기간이 7 개월에서 30 개월 이상으로 증 가된 싱태이다. ${ }^{8)}$ 근본적인 치료법은 항암화학요법으로 Melphalan과 Prednisone (M- P) 의 경구 항암제의 복합요 법이 가장 많이 사용되고 있다. ${ }^{499110)}$ SWOG에서 시도한 교차 항암화학요법으로 즉 $\mathrm{VMCP}$ (vincristine, mephalan, cy clophosphamide, prednisone) 과 VBAP(vincristine, $\mathrm{BCNU}$, adriamy cin, prednisone) 을 교대로 반복하는 방 법도 있다. ${ }^{811)}$ 생존기간에 있어서 두 화학요법간에 특별 한 차이를 보이지 않는다. ${ }^{12) 14) 15)}$

다발성 골수종에 대한 원인과 자연경과에 대해서는 잘 알려져 있지만, 측두골에 나타나는 경우, 보고된 예가 적 을 뿐 아니라 대부분 질환 말기에 나타나는 특성을 가 진다. ${ }^{12)}$ 측두골에 발생한 다발성 골수종의 이통, 이루, 청 력손실, 어지러움, 이명, 안면신경마비와 같은 국소적 증
상은 일반적인 염증성 질환 또는 종양의 증상과 구분이 어렵고, ${ }^{316-18)}$ 또한 측두골 내부에 주병변이 있는 경우, 조직검사가 어렵다는 해부학적 특성도 진단을 늦어지게 한다.

다발성 골수종은 전신질환이므로 측두골의 병변에 증 상완화를 위한 목적 이외에 치료 목적으로서의 수술은 초 기 치료방법으로는 적합하지 않으며, 일반적인 다발성 골 수종의 치료에 준해 치료방침을 세우는 것이 보통이다.

국소적 증상이 심하거나 통증이 심한 경우, 증상완화를 위해 항암 요법과 국소 방사선 치료를 사용하기도 한다. 1998년 악화되는 이통을 주소로 내원한 환자에서 외이 도의 종괴를 발견하고, 조직검사를 통해 다발성 골수종을 확인하고 항암 요법과 국소 방사선치료를 병행한 뒤 상 당한 호전을 보인 예가 보고되었다. ${ }^{12)}$ 1985년 다발성 골 수종으로 이미 진단 받은 환자에서 안면신경마비가 동반 된 예가 보고되었으며, 방사선학적 소견으로 다발성 골 수종이 측두골에 이환된 것으로 진단하고 국소적 방사선 치료를 한 후 안면신경마비가 회복되고, 측두골의 병변 부위가 사라진 예가 보고되었다. ${ }^{16)}$

본 증례는 기존에 다발성 골수종을 진단 받지 못한 상 태에서 난청, 이명 그리고 측두부의 종물을 호소하며 내 원한 뒤, 조직검사를 통해 처음으로 다발성 골수종을 진 단 받은 경우로 측두골에 종물이 있는 경우, 드물지만 다 발성 골수종을 포함한 형질세포 종양의 가능성을 고려해 야 한다는 점에서 의미가 있다.

중심 단어 : 다발성 골수종. 측두골. 이명.

\section{REFERENCES}

1) Clamp JR. Some aspects of the first recorded case of multiple myeloma. Lancet 1967;2:1354-6.

2) Willis RA. Principle of pathology. 2nd Ed. London: Butterworth;1961. p.554.

3) Lavine RF, Mattucci KF, Merton CW. Multiple myeloma of the temporal bone. Ear Nose Throat J 1979;58:210-3.

4) Keay D. Total bilateral hearing loss as a complication of myeloma. J Laryngol Otol 1988;102:357-8.

5) Yang YH, Kim TY, Kim BK. A statistical study of multiple myeloma in korea. The Korean Soc Hematol 1995;30:345-61.

6) Li W, Schachern PA, Morizono T, Paparella MM. The temporal bone in multiple myeloma. Laryngoscope 1994;104: 675-80.

7) Kim SW, Oh CH, Kim JH, Jung MK. A case of multiple myeloma involving temporal bone. Korean J Otolaryngol 
J Clinical Otolaryngol 2004;15:299-302

2002;45:1014-7.

8) Kim TY, Heo DS, Bang YJ. Combination chemotherapy with vincristine, melphalan and prednisone for multiple myeloma. The Korean J Int Med 1993;45:1-11.

9) Kyle RA. Newer approaches to the therapy of multiple myeloma. Blood 1990;76:1678-9.

10) Alexanian R, Dimopoulos M. The treatment of multiple myeloma. N Engl J Med 1994;330:484-9.

11) Batsakis JG, Fries GT, Goldman RT. Upper respiratory tract plasmacytoma. Arch Otolaryngol 1979;79:613-8.

12) Quinodoz D, Dulguerov P, Kurt AM, Ruefenacht D, Abele R, Allal AS, et al. Multiple myeloma presenting with external ear canal mass. J Laryngol Otol 1998;112:469-71.

13) Salmon SE, Haut A, Bonnet JD, Amare M, Weick JK, Du- rie BG, et al. Alternating combination chemotherapy and levamisole improves survival in multiple myeloma: A Southwest Oncology Group Study. J Clin Oncol 1983;1:453-61.

14) Oken MM. Standard treatment of multiple myeloma Mayo. Clin Proc 1996;69:781-6.

15) Bergsagel DE. Is aggressive chemotherapy more effective in the treatment of plasma cell myeloma. Eur J Cancer Clin Oncol 1989;25:159-61.

16) Shone GR. Facial palsy due to myeloma of the temporal bone. J Laryngol Otol 1985;99:907-8.

17) Chevalier X, Wrona NN, Larget-Piet B. Vestibular syndrome in multiple myeloma: Role of magnetic resonance imaging. Clin Rheumatol 1992;11:405-7. 